\title{
Abandoned Housing Projects in Malaysia: A Building Law Perspective
}

\author{
Nuarrual Hilal Md Dahlan \\ School of Law, Universiti Utara Malaysia, UUM Sintok, Kedah Darulaman, Malaysia
}

\begin{abstract}
Housing programme has been robustly implemented in Malaysia since Independence. At the commencement of the programme, the Federal Government provided housing accommodation to its citizens. However, due to the high demand for housing and the inability of the Government, the Government invited private sector to cooperate in supplying housing. Several laws have been enacted to control the housing industry. Among the laws are the Street, Drainage and Building Act 1974 (Act 133)('SDBA') and the Uniform Building By-Laws 1984 (G.N.5178/1984) ('UBBL'). Despite there are various housing policies and legislations to support housing programme, there are still many problems arising from the housing programmes in Malaysia. An example of the problems is the abandoned housing projects. Since the 1970s until todate, this issue is still occurring in Malaysia. Many purchasers have become aggrieved, suffered damage and losses. This paper aims to highlight the problems of abandoned housing projects through the analysis of building laws in Malaysia. This paper used qualitative case study and legal research methodologies to analyse the issues and to meet the research objectives. Through this paper, it is evident that there are weaknesses in the building laws. Hence, appropriate amendments and improvements to the laws should be made to empower the laws and provide adequate measures against the issues. The results of this paper will provide new ideas to housing practitioners and policymakers in dealing with the problems of abandoned housing projects in Malaysia towards achieving the $11^{\text {th }}$ Malaysia Plan and National Housing Policy (2018-2025)('DPN').
\end{abstract}

Keywords: abandoned housing projects; building law; housing policy; legal issues; proposals.

\section{Introduction}

After Independence in 1957, Malaysia, as a new nation has embarked on to establish various means and objectives to develop it to become a sustainable and prosperous country in the world. Thus, the Government has initiated various development plans and with the participation of the private sector. The essential development plans are the consecutive 5 year of Malaysia Plans. The current latest Malaysia Plan is the $11^{\text {th }}$ Malaysia Plan that covers between the year 2016 until 2020.

One of the objectives of the Malaysia Plans is to provide quality, affordable and adequate housing to its citizens. Thus, various housing programmes have been carried out firstly by the Federal Government and later with the help of the private sector. Thus, in every part of Malaysia, one can witness the pervasive booming development of housing projects. For the citizens, the available stocks of housing units mean they will be guaranteed with sufficient 
shelter and place of abode. For the Government, the existence of robust development of housing development has helped it to achieve the objectives in the Malaysia Plans, DPN and energise the economy. While for the private sector, the opportunity to participate in housing industry means providing them with sources of profit and wealth to the respective shareholders and stakeholders. Thus, many layers and segments of society receive the benefits of housing development industry.

Be that as it may, housing development in Malaysia has certain spilt over effects and setbacks. Among these are poor workmanship, projects delay, abandoned housing projects, problematic housing projects and other consumers' grievances due to the default of the developers, constructors and consultants.

Housing development process involves various stages. The first one is the land stage. This is followed by planning, building and pre-construction stage. Later there is a construction stage and finally, post-construction stage. In every stage, some authorities and laws govern the stage. For land stage, the relevant authorities will be the state authority and the land office. Under the planning, building and pre-construction stage, the responsible authorities are the planning authority, local authority and technical agencies. While under the construction stage and the post-construction stage, the governing authorities are the Ministry of Housing and Local Government (KPKT), the technical agencies and the local authority. Technical agencies are agencies that provide views and recommendations to the local authorities, local planning authorities and consultants before certain building and construction approvals can be issued in respect of water, electricity, public road, and other infrastructures. Examples of the technical agencies are the electrical authority - Tenaga Nasional Berhad (TNB), water authority, Public Works Department (JKR) and Department of Drainage and Irrigation (JPS). These housing development stages and authorities are governed by various laws and statutes Among the laws involved are the land law National Land Code 1965 (Act 56)('NLC'), Land Acquisition Act 1960 (Act 486), Town and Country Planning Act 1972 (Act 176)('TCPA'), Street, Drainage and Building Act 1973 (Act 174)('SDBA'), Uniform Building By-laws 1984 ('UBBL') and Housing Development (Control \& Licensing) Act 1966 (Act 118) and its regulations ('HDA'). The existence of these authorities and laws is to ensure the rule of law, good environment, life sustainability and preserve the safety, security and rights of the stakeholders including the house residents. Above all, these laws are to ensure that the constructed house buildings are fit for human habitation.

This writing focuses on the building law that involves the SDBA and the UBBL This writing involves legal analysis and discussion of the relevant legal provisions, case law and problems that involve in abandoned housing projects.

\section{General Issues Involving Building Laws in Abandoned Housing Projects in Malaysia}

It is a trite fact that the technical agencies and the local authority prescribe conditions for the approved building plan and other infrastructure plans. These conditions must be met by the applicant developer for them to be given the Certificate of Fitness for Occupation (CFO) or the Certificate of Completion and Compliance (CCC), as the case may be. The SDBA and the UBBL confer them this power. Nonetheless, it is submitted that there are times that the conditions imposed by the local authority are unjust to the developers and finally may affect the smooth development progress of their housing development projects. This issue can lead to abandonment. For instance, there is proof that the local authority has imposed additional conditions, at the end part of the completion of the project or in the middle of the development, 
as a condition precedent for the issuance of CF or CCC. However, these conditions have not been stipulated earlier for immediate action of the developers. Secondly, the failure of the developers to fully comply with the prescribed conditions, resulting in the failure to obtain the necessary $\mathrm{CF}$ or CCC, before the project can be considered complete and fit for human habitation. These issues and problems occurred in a housing project as reported in Tang Kam Thai and 133 Others $v$ Langkah Cergas Sdn Bhd and Others [2005] 1 MLJU 248 (High Court of Malaya at Kuala Lumpur), in housing projects at Taman Temiang Jaya, Seremban, developed by AMA Construction Sdn. Bhd and at Wisma Telaga, Butterworth (previously known as Wisma ABC, Lot 3681, Jalan Telaga Air, Seksyen 4, Butterworth, Seberang Perai Utara, Pulau Pinang, developed by Tropiland Sdn. Bhd (Ministry of Housing and Local Government file numbers: KPKT/08/824/2605, KPKT/08/824/7347-I, KPKT/08/824/2732-01, KPKT/08/824/1843; Tropiland Sdn. Bhd. v. Majlis Perbandaran Seberang Perai [1996] 4 MLJ 16 (High Court of Malaya at Penang); Majlis Perbandaran Seberang Perai v. Tropiland Sdn. Bhd. [1996] 3 MLJ, 94; [1996] 3 CLJ 837 (Court of Appeal); Aw Yong Wai Choo \& Ors v. Arief Trading Sdn. Bhd \& Anor [1992] 1 MLJ 166) (High Court of Malaya at Ipoh).

There are also evidences that in some situations where there is no specific requirement imposed by the local authority, under the stage of plans' approvals (building, infrastructure plans and other plans), on the applicant developers to obtain comments from the Department of Minerals and Geoscience (JMGS) and Department of Environment (JAS) over the sites of the housing development projects. It also seems that these technical agency departments would still be needed to carry out certain feasibility studies over the purported sites on which the housing developments are to be implemented. It is submitted, the professional comments may be necessary, to avoid any possible occurrence of abandonment of the housing development projects due to the soil structure, which may involve additional costs to the developers. This problem happened at Taman Dayang, Mukim Kuah Langkawi (developed by INI Holding Sdn. Bhd.), Taman Perwira, Jerantut, Fasa II, (problems with the geotechnical soil and land of the project) developed by Yee Hoong Loong Corporation Sdn. Bhd. and Taman Harmoni, Lot 82, Mukim of Cheras, District of Hulu Langat, Selangor (problem of slime soils). A similar problem also occurred at Taman Villa Fettes, Lot 141 dan 3622, Mukim 18, NED, Pulau Pinang, where it was found that the project had to be abandoned because the developer had incurred substantial expenditure to extract and remove hidden hard rocks/granite in the soil of the project sites (Ministry of Housing and Local Government, n.d; Ministry of Housing and Local Government file numbers: KPKT/08/824/63 97-1, Jld 2, KPKT/BL/19/6397-I, KPKT/08/824/4285-1, KPKT/08/824/3947-5, KPKT/08/824/6037-1; Syarikat Chang Cheng (M) Sdn. Bhd v Pembangunan Orkid Desa Sdn. Bhd. [1996] 1 MLJ 799 (High Court of Malaya at Kuala Lumpur).

During the rehabilitation of abandoned housing project, the rehabilitating parties may have to obtain permission to use or renew the prior approved plans from the building authority. Nonetheless, if section 25 of the TCPA are triggered, the rehabilitating parties have to apply for new building plans or other plans because the approved plans have to be amended in compliance with the new conditions of the relevant authorities. This situation may happen when the building authority feels necessary for the building authority, in public interest or ensuring the house building is fit for human habitation, to revoke or amend the previous approved building plan. The use of the previous building plan could be seen in the rehabilitation of Taman Yew Lean, Lot 664, Section 2, North East District (NED), Pulau Pinang (developed by Yew Lean Development Sdn. Bhd), where the rehabilitating parties were allowed to use the previous plan without any modification, by Majlis Perbandaran Pulau Pinang (Penang 
Municipal Council) ('MPPP')(being the local planning authority/local authority/building authority) to smoothen the rehabilitation programme. Likewise, this also happened in Taman Batu Bukit, Lot 1384, Mukim 1, Tanjung Tokong, North-East District (NED), Pulau Pinang (developed by Vigol Development Sdn. Bhd.). Usually, in the rehabilitation of abandoned housing project, the local planning authority/local authority/building authority and technical agencies are required to give necessary cooperation to streamline the smooth running of the scheme. These cooperations include expediting the approval of the plans, the issuance of $\mathrm{CF}$ or $\mathrm{CCC}$ and relaxing the rigorous administrative and legal requirements and providing certain exemption of contributions in order to expedite the completion of the project and reducing the rehabilitation costs (Ministry of Housing and Local Government file numbers: KPKT/08/824/365,KPKT/08/824/1910, KPKT/BL/19/1171-1, KPKT/(05)/1910, KPKT/08/824//337, KPKT/08/824/153/E, KPKT/08/824/2605; Ministry of Housing and Local Government, Division of Supervision and Enforcement, n.d.).

The author also submits that the existing Malaysian law too is overly protective to the state authority and local authority (building authority) even though they are proven having been negligent and failed to exercise due care before granting approvals for housing development in respect of the requirements under the SDBA and the UBBL.

The historic collapse of Highland Towers' case in 1993 is also an example of the issue of soil problems in housing projects in Malaysia. This event also proved that the law protects the local authority and state authority even though they are negligent and breach of statutory duty. This disaster had been highlighted in reported case law - Steven Phoa Cheng Loon \& Ors v Highland Properties Sdn Bhd \& Ors [2000] 4 MLJ 200; [2000] 3 AMR 3567 (High Court of Malaya at Kuala Lumpur), Arab-Malaysian Finance Bhd $v$ Steven Phoa Cheng Loon 7 Ors and other appeals [2003] 1 MLJ 567 (Court of Appeal at Kuala Lumpur) and Majlis Perbandaran Ampang Jaya v. Steven Phoa Cheng Loon \& Ors [2006] 2 CLJ 1; [2006] 2 MLJ 389 (Federal Court). Highland Towers involved a huge building that collapsed due to the weakening soil and soil settlement surrounding the foundation of the building. The official death toll was 48 people. However, other sources said it reached 50 people. Most of the victims were Malaysians and 12 foreigners. Behind the Highland Towers' buildings, there was a small water stream. This water stream was naturally diverted into the site of the Highland Towers before its construction. A piping system was made to deviate this flowing water into other place bypassing the tower. However, in 1991, a new housing development project was erected on the top of a hill behind the Highland Towers. The developer of this project had cleared off the trees and other land covering plants on the hill. This land clearing had caused soil erosion to the hill (Wikipedia, 2020).

Due to this new housing development, the water that was once absorbed by the hilltop was now pooled into the piping system. This happened in November 1993. As a result, this caused the pipe burst and could not sustain the large amount of water. The overflowing burst water had caused the flowing of substantial water into the foundation of Highland Towers. Overwater saturation occurred at the foundation site of Highland Towers and the hill slopes. As a result, the foundation soil on which Highland Towers stood could not sustain and support the weight of the buildings and caused the collapse one of the towers - Block 1. This happened on 11 December 1993 (Wikipedia, 2020).

Rescue teams came from the Federal Reserve Unit (FRU), military personnel, engineers, policemen, fireman, KL City Hall rescue team, and Malaysian Red Cresent Council volunteers. Apart from this, after a few days, rescue teams from France, Singapore, United Kingdom, 
United States and Japan came to help. Due to the instability of the foundation, occupants in Blocks 2 and 3 were required to vacate their units. The rescue teams worked until 21 December, including using heartbeat detectors, rescue dogs, dug a 4.5 meters hole for access, steel machines and breaking concrete, and using bulldozers to remove debris to clear off the collapse building area. By 21 December it was official that the rescue teams found 48 bodies from the Highland Towers debris (Wikipedia, 2020).

Currently blocks 2 and 3 are left vacant as the foundations are not safe for the buildings. Occupants are not allowed to reside in the blocks. The 2 blocks are now left abandoned and become subject of vandalism, in complete disarray, a haven for drug addicts, criminals, and used by mat rempits (illegal public road racers) as temporary shelters. In this case, the High Court found the Highland Towers' three (3) apartment blocks were erected on an elevated land with a relatively flat foundation with a steep hill behind the building blocks. Some witnesses have explained the gradient of this hill to be 10 to 20 degrees, but the judge found the various photographs tendered to be far steeper (Wikipedia, 2020).

In this case, the local authority - building authority (Majlis Perbandaran Ampang Jaya (MPAJ)) was held not liable pursuant to section 95(2) of the Street, Drainage and Building Act 1974 (Act 133) ('SDBA'), by the Federal Court, for the collapse of Highland Towers which comprised of three blocks of apartment due to failure of MPAJ to provide a master drainage plan for the affected area on the hill slope behind Highland Towers and to implement it, as required by sections 53 and 54 of the SDBA. The purported master drainage is to ensure the stability of the adjacent Blocks 2 and 3. The exemption from liability of MPAJ covered the negligence of MPAJ's omissions prior to the collapse of Block 1 of the Highland Towers as well as for the post-collapse liability. According to the Federal Court (Abdul Hamid Mohamad and Ariffin Zakaria FCJJ), apart from section 95(2) of the SDBA exempting any liability of the local authority, in view of the public policy, responsibilities, burdens and limitations of the local authority and the local circumstances, it was not reasonable to impose such a burden of liability (pre-collapse liability and post-collapse liability) on MPAJ (the local authority). Abdul Hamid FCJ reasoned on the basis of balancing interests between the interest of the local authority as well as the ratepayers in Malaysia and their constraints and that of the interests and losses suffered by the plaintiffs, i.e. the public policy, local circumstances, responsibilities, burdens and limitations of the local authority (MPAJ) as compared to the injuries and losses sustained by the respondents.

Before the case was brought to the Court of Appeal and the Federal Court, the High Court judge only exempted the liability of MPAJ from the pre-collapse liability, not the post-collapse liability. However, in the Court of Appeal, on appeal of MPAJ, the post-collapse liability was also exempted. While, in the Federal Court, Steve Shim CJ (Sabah \& Sarawak), in minority, decided that MPAJ was still liable for post-collapse liability as MPAJ could not seek any protection under section 95(2) of the SDBA. Steve Sim CJ opined that this was a case of negligence, on part of the building and local authority, in failing to implement certain required works as prescribed by the SDBA. The negligence involved a complete failure of works to be done, where if the works were done, they (the works done) would have immunised MPAJ from liability for negligence under section 95(2) aforesaid. However to Abdul Hamid Mohamad and Ariffin Zakaria FCJJ (in the Federal Court) the post-collapse liability was also exempted, not on the basis of section 95(2) of the SDBA but based on public and balancing interest.

The High Court decided that the housing developer was negligent for not appointing a qualified architect to prepare the building plans. Both the first defendant housing developer and second 
defendant were found to be negligent for providing inadequate terraces, retaining walls and drains on the hill slope, which could reasonably have been foreseen to have caused the collapse. The High Court also found that the third defendant, an engineering firm, was also negligent and acted in contravention of the SDBA. The registered architect and engineer too were found to have been negligent for obtaining a Certificate of Fitness (' $\mathrm{CF}$ ') without fulfilling the conditions of the Local Authority. In other words, the registered architect and engineer had not monitored the terracing of the hill slopes and construction of retaining walls even though they were aware that the instable hill slopes would affect the nearby buildings. The third engineer was also found in negligence for not having examined the hill or slope behind the towers adequately and failed to construct a foundation to accommodate the lateral loads of a landslide or alternatively to have ensured that the adjacent hillslope was fit and sound.

Based on the Highland Towers' case, the judicial decision proved that the professionals engaged by developers are liable if they are found to be careless or neglecting their duties where they owed a duty of care to the house purchasers. This legal issue served as an example of the legal problems involving soil problems in housing development in respect of professional's negligence and human error.

Nevertheless, despite there was a compensation of MYR 59 million (USD 14,169,062.32) paid by the defendant AmBank Finance to the 139 victim resident, the amount was inadequate (The Star, 2004). Further, there is no information, either, of the legal and equitable remedies given to the purchaser residents who formerly occupied Blocks 2 and 3 who had been forced to vacate the premises due to the dangerous situations. According to Afandi Yahya and Muhammad Zhariff Afandi, being tenants in one of the Highland Towers building units, there was no compensation for the losses and sufferings of the victims paid by the developers and other parties as consequence of the catastrophe. (Afandi Yahya, personal communication, February 23, 2021; Muhammad Zhariff Afandi, personal communication, February 12, 2021).

The current news is that the other two abandoned apartments of the Highland Towers (Blocks 2 and 3) which have been vacated due to safety and security purposes are planned to be demolished by June 2019. These apartment buildings have been abandoned since the last 27 years. The authorities who are responsible for the demolition of these building are the Public Works Department (JKR) and the Ampang Jaya Municipal Council (MPAJ) (being the local and building authority). The previous developer agreed to donate MYR 2 million (USD $468,871.00)$ to the authorities as costs to demolish the buildings. The site location is not suitable for housing development, but according to the authority, the site will be used for a recreational park (Shahrul Annuar, 2019; Bernama, 2019).

Part of the issues involving soil problems in housing development projects is due to the decision of the court in Majlis Perbandaran Pulau Pinang v. Syarikat Bekerjasama-sama Serbaguna Sungai Gelugor Dengan Tanggungan [1999] 3 MLJ 1 (High Court of Malaya at Penang). The decision of this case marginalises the provision of the development plan, even though compliance with it is mandatory according to the Town and Country Planning Act 1976 (Act 172) ('TCPA'). Thus, this case may lead the Planning Authority and State Planning Authority not to follow the TCPA provisions. What more for these authorities to abide by the views of the technical agencies?

However in Perbadanan Pengurusan Trellises \& Ors V. Datuk Bandar Kuala Lumpur \& Ors [2021] 2 CLJ 808 (Court of Appeal at Putrajaya), the Court of Appeal held that the Local Planning Authority is duty bound to follow the Development Plan. 
In this case the developer in a Joint Venture agreement with the land proprietor agreed to developer a land which was meant to be a public open space, green area and recreational area for the general public, in accordance with the gazetted Kuala Lumpur Structure Plan 2020 ('KL Structure Plan') and the draft Kuala Lumpur Local Plan 2020 ('KL Local Plan'). The developer intended to develop the land into a block of affordable apartments and eight blocks of luxurious service apartments with an eight storey podium carpark. The developer applied for a development order (Planning Permission) to develop the said land to the Datuk Bandar Kuala Lumpur (the First Respondent). The appellants objected to the proposed development on the ground that it would significantly increase the density of TTDI and irreversibly degrade Taman Rimba Kiara as a green lung.

The appellants commenced a judicial review application, at the High Court, seeking:

a) orders of certiorari to quash the conditional planning approval and the development order on the grounds that the decisions were tainted with illegality, irrationality and procedural impropriety;

b) the appellants had a legitimate expectation that the subject land would remain as a public open space, recreational, sports and green area and a city park; and,

c) an order of mandamus directing the Datuk Bandar to adopt the KL Local Plan and to publish the adoption in the Gazette pursuant to s. 16 of the Federal Territory (Planning) Act 1982 ('Act').

In support of their application, the appellants submitted that, inter alia, (i) rule 5(8) of the Planning (Development) Rules 1970 ('Rules') requires the Datuk Bandar to convey to the relevant persons a written decision on the application and the objections raised. There was procedural impropriety in that $\mathrm{r}$. 5(8) of the Rules had not been complied with as no reasons were given to the appellants for the Datuk Bandar's decision; (ii) the Datuk Bandar's decision contravened s. 22(1) of the Act when it failed to consider the KL Structure Plan and the KL Local Plan in that under the KL Structure Plan, the subject land had been demarcated as a public open space, recreational and sports area, green area and city park; whilst the KL Local Plan had demarcated Taman Rimba Kiara as a city park and public open space with zero development intensity; (iii) there was a conflict of interest because the Datuk Bandar was a member of the Board of Trustees of the second respondent and the application for planning permission was made in the joint names of the first and second respondents. But the High Court dismissed the application of the appellants. Hence the appellants appealed to the Court of Appeal.

The Court of Appeal held, inter alia, that, Section 22(4) of the Act confers the Datuk Bandar, as the Commissioner, a discretion in relation to whether an application for planning permission ought to be favourably or otherwise considered, with or without terms and the nature of those terms to be imposed. This discretion is not unfettered. In the context of s. 22(4) of the Federal Territory (Planning) Act 1982 ('the Act'), and this is recognised in s. 22(1) of the Act itself, the expression used is 'shall'. The Datuk Bandar is directed to take into consideration such matters as are expedient or necessary for the proper planning of the development, and the local area. Even in that regard, it is not open ended. The Datuk Bandar is specifically directed to have regard to the provisions of the development plan and where the local plan has not been adopted, the comprehensive development plan (CDP); and any other material consideration. Clearly and quite obviously, the CDP, structure plan and local plan are material considerations. If these plans were not taken into regard at the material time, the decision reached is invalid; and no 
reason or explanation given later at the judicial review proceedings could change that as it must be apparent from the decision communicated to the appellants how the concern about the KL Structure Plan was addressed.

Be that as it may, the State Authority has an upper hand over the views of the professional advice. This is reinforced by section 108 of the National Land Code 1965 (NLC) and that any negligence of the Local Authority and the State Authority is protected by section 95(2) of the Street, Drainage and Building Act 1974 (Act 133)('SDBA')(Md Dahlan, 2009).

\section{Objectives}

The objectives of this writing are as follows:

1) To examine the building laws involving abandoned housing projects in Malaysia;

2) To analyse the issues in building laws involving abandoned housing projects in Malaysia;

3) To recommend certain new ideas to improve the current building law to accommodate the current needs and preserve the interests of relevant parties against the problems of abandoned housing projects in Malaysia.

\section{Research Methodology}

The research methodology that is applied in this research writing is a composite of legal research and qualitative case study social research. The legal research involves the analysis of the relevant legal provision of the building laws under the SDBA, UBBL and the relevant case law. The objective of legal research is to find out the weaknesses of the current building laws in Malaysia that have caused the problems of abandoned housing projects. By analysing the legal provisions and the data from social fieldwork in two Malaysian abandoned housing projects' case studies, i.e. Taman Harmoni, Cheras, Selangor and Taman Lingkaran Nur, Kajang, Selangor, the author believes that salient, more profound, detailed and subtle issues and weaknesses of the building laws can be discovered, analysed and resolved. The sources of legal research are mainly from the provisions under the SDBA and the UBBL. Relevant case law will also be analysed to support and illustrate deeper the statutory provisions. The case law are the reported case law from Malayan Law Journals, Current Law Journal and All Malaysian Reports obtained either through manual library research or through internet sources. The case law function is to corroborate, illustrate, expound and consolidate the understanding from analysis of the statutory building laws. Some other secondary sources that are used to enhance the legal data include circulars, guidelines and directives of the relevant authorities. While the case study, qualitative research will involve the above two (2) abandoned housing projects. The objective of the case study qualitative research is to get detailed and more meaningful information and data on certain focused subject matters. This method will have characteristics of exploratory, descriptive and explanatory case study research over the two (2) abandoned housing projects and the analysis of the relevant building laws and the legal issues. The questions of 'how' and 'why' will be used to investigate these two (2) abandoned housing projects. The selection of the two (2) case studies are done through purposive sampling. The samples are two abandoned housing projects, as mentioned above. The sources of data for case study qualitative research are the available files of the local authority - Majlis Perbandaran Kajang (MPKj) and the Ministry of Housing and Local Government (KPKT). Apart from the 
accessible files, the author also conducted interviews with relevant officers, developers and aggrieved purchasers. Through these multiple evidences and triangulation method, the objective of making this research writing a valid and reliable research exercise and the outcome can be achieved (Yin, 2003; Yin, 2014; Silverman, 2000; Silverman, 2005; Silverman, 2018; Zahrah, 1998; Dobinson \& Johns, 2007).

\section{Literature Review}

Concerning this writing, certain words warrant for definitions. The first is 'building law'. According to Oxford Advanced Learner's dictionary, building means 'a structure such as a house or a school that has a roof and wall'. Secondly, it can mean 'the process and work of building'. While the word 'law' means, according to the same dictionary, inter alia, means 'a rule that deals with a particular crime, agreement, etc.'.

According to "Law Insider Resource Center", 'building law' means 'a law generally regulating building construction and demolition'; "building permit" means 'a permit or consent to carry out building work issued under a building law or planning and development law of a participating jurisdiction' (Law Insider, 2012).

Thus, 'Building law' it is submitted is a law that governs the development and construction of building particularly the laws that contained in the Malaysian Street, Drainage and Building Act 1974 (Act 133) ('SDBA') and the Uniform Building By-Laws 1984 (GN 5178/1984)('UBBL').

The second important word in this writing is 'abandoned housing project'. According to the Oxford Advanced Learner's dictionary, it means among other things, 'left and no longer wanted, used or needed'. While 'housing' is defined among others as 'houses, flats/apartments, etc. that people live in especially when referring to their type, price or condition'. While the word 'project' means, inter alia, 'a planned piece of work that is designed to find information about something, to produce something new, or to improve something'.

According to the Ministry of Housing and Local Government (KPKT), 'abandoned housing project' is a housing development project that:

a) has not been completed by the housing developer within or beyond the sale and purchase agreement (SPA) period and no significant activity on the construction site for 6 months continuously; or,

b) The High Court has issued a winding-up petition against the housing developer under section 218 of the Companies Act 1965; or,

c) The housing developer is put under a Receiver \& Manager; or,

d) The housing developer admits his inability to complete the housing project to the Housing Controller; and,

e) The Minister of Housing and Local Government confirmed that the problematic project as an abandoned project under section 11(1)(a) of Act 118. (Portal Rasmi Jabatan Perumahan Negara, Kementerian Perumahan dan Kerajaan Tempatan, 2012).

Among the reasons leading to the abandonment of housing projects, according to KPKT, are as follows:

i. $\quad$ the housing developer fails to manage company/project expenses reasonably;

ii. the housing projects that have been launched have not received sufficient purchases resulting in poor profit margins;

iii. the housing developers fail to make proper Return of Investment (ROI) studies; 
6-8 August 2021

Budapest, Hungary

iv. Fluctuations in the building material prices that have caused housing developers unable to continue the project at the projected costs; and,

v. The housing developer companies' projected planning is influenced by the growth and volatility of the world economy, for example, the 1997 economic crisis had caused many companies to have failed in businesses (Portal Rasmi Jabatan Perumahan Negara, Kementerian Perumahan dan Kerajaan Tempatan, 2012).

According to the KPKT, the followings are the repercussions of the occurrences of abandoned housing projects in Malaysia:

1) Purchasers need to repay the loan to the financiers even though the houses have not been duly completed.

2) Stakeholders such as landlords, contractors, financiers, purchasers and developers will face various legal implications. This may lead to dishonest manipulation by certain parties. This problem can also cause rehabilitation efforts difficult;

3) The original defaulting developers or the later rehabilitating developers will have difficulty in obtaining funds either through bank loans or investors or having problems in selling the remaining unsold units to restore healthy cash flow.

4) The reputation of the Malaysian housing industry will be tarnished as abandoned housing projects problem has created a wrong perception to potential house purchasers and the investors (Portal Rasmi Jabatan Perumahan Negara, Kementerian Perumahan dan Kerajaan Tempatan, 2012).

Below are relevant literature on abandoned housing projects in Malaysia that have been analysed. Nevertheless, the discussion and analysis do not focus on building law and its issues. These writings are also based on non-legal writings. While the legal analyses and writings on abandoned housing projects in Malaysia have not so far, specifically, addressed the building law and its issues. The information on abandoned housing projects in Malaysia through this literature are elaborated below.

In 2015, the Malaysian Government proposed that a new system of housing delivery that should be adopted to prevent any occurrence of abandoned housing project. This system is known as a 'full build then sell system' or '10-90 system'. Nonetheless, this proposal was not well received by the housing developers. The issues of this new system are that the bank lenders disagree with funding the projects. Only the most qualified financially will be able to implement the delivery system, not for the non-qualified as these developers cannot get the progressive funds from the purchasers. There is no guarantee that the purchasers will pay the balance $90 \%$ money once the housing projects have been completed thus detrimental to the developers' cash flow finance. Further, the supply of housing units will be decreasing as only financially stable developers will be able to implement this new system. In addition, the incentives offered by the Government for the developers to embark on implementing this new system are not attractive. As the result, this proposed system cannot be implemented and that the KPKT to assume the responsibility to rehabilitate abandoned housing projects in Peninsular Malaysia (Siew-Nooi \& Tech-Hong, 2016).

According to Abdul Razak, one of the problems of abandoned housing projects is due to the issues of unjust Islamic home finance contract between the purchasers and the developers, particularly the Bay' Bithaman al-Ajil (BBA). According to Abdul Razak, the terms in the BBA are one-sided and do not protect the interests of the purchasers. However, according to him, the 
better Islamic Finance Product is Musharakah Mutanaqisah (MM), which according to him, contains equitable and fair term to both purchaser borrower and the bank (Abdul-Razak, 2016). Such contention on the better equitable position of Musharakah Mutanaqisah in facing the issues of abandoned housing projects is supported by Abdul Razak, et al (2015).

Abdullah \& Abdul Rahman (2012), identified the risks in the rehabilitation of abandoned housing projects and how the rehabilitation parties should deal with their rehabilitation. Further, this article journal analyses the risks associated with abandoned housing projects. These risks include construction, environmental impacts, law, politics, materials, management, finance, and economy. Thus, the issues of abandoned housing projects in Malaysia entail dynamic aspects which need to be explicitly addressed. To Abdullah and Abdul Rahman (2012), the pertinent risks relating to housing abandonment are risks due to unforeseen ground site condition, project delays, the bureaucracy of the government machinery, contractual issues between developer and landlord, inadequate management by novice developer, and financial management issue. Besides, it is also found that delay in delivery of material supply to site project, lack of material supply, and also economic downturn are deemed as significant factors contributing to the problems of housing abandonment. Thus, to overcome these risks, this paper suggests that before embarking on the purported housing development projects, the developers should conduct a feasibility study to enable the developers to be wary and aware at the outset with the possible risks that can lead to abandonment. Likewise, Abdul-Rahman, Alashwal, Ayub \& Abdullah (2013) restated similar risks that plague abandoned housing projects' rehabilitation.

Sulaiman, Ali, \& Ahmad (2012) revealed the dissatisfaction of the residents of abandoned housing projects on matters of the building quality. This involves the problems of building structure, building materials, stability of the buildings, construction quality works and environmental quality.

Muhammad, \& Ahmad (2014) discussed the situations involving musharakah mutanaqisah Islamic Home Finance product ('MM') in abandoned housing projects. According to them, if a housing project is abandoned, the IHF product musharakah mutanaqisah's profits that the Islamic banks may obtain will be significantly reduced. However, Islamic banks can ensure that they will retain a stable and guaranteed level of profits through MM by inserting some terms in the agreement.

Khalid (2010), on the other hand, focused on the issues and applicability of neo-classical and institutional theories in property and land market analysis, the worldview of abandoned housing projects, focusing on institution affecting housing development in Malaysia, analysing the role of market signal and emphasising the causes of abandoned housing projects and suggesting appropriate policies to prevent and solve the issue of abandoned projects. He opined that the cause of abandonment relates to institutional causes and institutional failure to react sufficiently to housing abandonment market signals.

On the other hand, Mumin, Zainol, \& Wan Daud (2017), emphasised the approach to deal with abandoned housing projects by blue ocean strategy. While Salam, Ariffin, Nur Aseykin, Noram, \& Ramli (2019) pinpointed that the condition of 30\% houses that developers should provide for the low-income people is a significant factor that can cause housing abandonment. This condition affects the financial capability and monetary inflow of the developer to meet all the expenditure for completing their housing projects.

Md Dahlan embarked on legal analyses over certain types of laws that are interconnected in abandoned housing projects. These laws include the Malaysian land law, planning law, housing 
development law, corporate insolvency law and Islamic Home Finance Law. According to him, under the land law, one of the problems in the law and policies is the failure of the State Authority to appoint suitable housing developers to implement housing development projects. Further, the state authority failed to identify and granted suitable land for sustainable housing development. It is evident that incapable developers have been appointed to implement housing development projects and that land location for housing development is prone to landslide, land erosion, soil settlement and unsuitable soil contents and structure. All these have caused exorbitant costs to the developers who faced shortage of funds in completing the projects (Md Dahlan, 2014, A; Md Dahlan, 2016; Md Dahlan, 2012; Md Dahlan, 2014, B).

In respect of planning law in Malaysia, Md Dahlan found that inadequate references and views from relevant technical agencies is one of the reasons that has caused the non-suitability of land location for housing development. For instance, failure of the planning authority to refer to the soil authority for latest information on the suitability of the land location. The investigations and inquiries of the planning authority are mostly ad hoc, not thorough. There is no requirement and condition that prospective housing developer must carry out soil investigation (SI) to ensure the land location is suitable. Similarly, this point has not been emphasised in the development plans (Local and Structure Plans) for land use planning in Malaysia either (Md Dahlan et al, 2019).

Concerning housing development law, Md Dahlan stressed that the inadequate enforcement by the Ministry of Housing and Local Government (KPKT) is the major problem in the struggle to contain the occurrences of abandoned housing projects. Further, he asserted that the weaknesses of Malaysian Housing delivery system 'full sell then build' is also an issue where this has opened the possibility of abandonment. Also, there is no requirement of the KPKT imposing on the developers to get Housing Development Insurance ('HDI') as a monetary support if the developers fail to complete the projects. Apart from these weaknesses, Md Dahlan also pointed out that there is no specific legal framework governing rehabilitation. This can cause abuse of power and position of the rehabilitation parties, for instance, the rehabilitating developers, contractors, architects and engineers, to the detriment of the aggrieved purchasers (Md Dahlan, 2019, A; Md Dahlan, 2015, A; Md Dahlan, 2015, B; Md Dahlan \& Masum, 2014; Md Dahlan, 2011, C; Md Dahlan, et al, 2010; Md Dahlan \& Md Desa, 2010; Md Dahlan, 2008, B; Md Dahlan, 2007, A; Md Dahlan, 2007; Md Dahlan, 2007, C; Md Dahlan, 2006; Md Dahlan, 2011, A; Md Dahlan, 2011, B).

While in respect of corporate insolvency law and legal issues, Md Dahlan submitted that the current insolvency administrations are in the state of creditors' centric. The law marginalises the interests and rights of the aggrieved purchasers. Thus, in the chronic situation, the purchasers in abandoned housing projects may not get any refund or protection as the creditors have not agreed and the monetary provisions from the insolvency administration are not sufficient to meet the purchasers' losses. The insolvency administrations relating to abandoned housing projects that have been analysed are liquidation, scheme of arrangement ('SoA'), receivership, corporate voluntary arrangement ('CVA'), judicial management ('JM'), and administration (Md Dahlan, 2015, C; Md Dahlan, 2014, B; Md Dahlan, 2014, C; Md Dahlan, 2013; Md Dahlan, 2012, B; Md Dahlan, 2012, C; Md Dahlan \& Syed Abdul Kader, 2012; Md Dahlan, 2011, D; Md Dahlan, 2008, A; Md Dahlan, 2014, E). 
Md Dahlan also contended that the Islamic Home Finance ('IHF') products particularly Bay' Bithaman al-Ajil ('BBA') is void and unjust to purchasers. He also pointed out that there are other types of IHF products contain terms which are one-sided favourable to the Islamic banks and unfair to purchasers. These products include the Ijarah Mausufah Fi Zimmah, Musharakah al-Mutanaqisah and Commodity Murabahah. Md Dahlan also submitted that the statutory formatted agreement of sale under Schedules G, H, I and J of the Housing Development Regulation 1989 are not shariah compliant as the agreement contain gharar element (uncertainty) and provide no protection to the aggrieved purchasers in abandoned housing projects (Md Dahlan, 2019, B; Md Dahlan, 2018, A; Md Dahlan, et al, 2018; Md Dahlan, 2018, B; Md Dahlan, et al, 2017; Md Dahlan, et al, 2017; Md Dahlan, et al, 2016; Md Dahlan, 2014; Md Dahlan \& Syed Abdul Kader, 2011; Md Dahlan \& Syed Abdul Kader, 2010; Md Dahlan, 2009).

Nevertheless, the above writings and researches reveal that none have focused and analysed the building law and its issues in abandoned housing projects in Malaysia. Thus, there is a gap in the aspect of building law. This writing will fill in this gap, and the author believes it can contribute to new ideas and approaches to deal with the problems of abandoned housing in Malaysia.

\section{Significance}

This paper is significant as it examines the law and issues in abandoned housing projects in Malaysia, in respect of the building law under the provisions of the UBBL and SDBA. As abandoned housing projects problem is kept on recurring in Malaysia, despite this has been realised by the Government and the public since the 1970s, the approaches that have been undertaken to deal with this problem, it is submitted, are still inadequate and ineffective. This problem has and will mar the due progress of the housing objective set out in the Malaysian plans, particularly the current $11^{\text {th }}$ Malaysia Plan (2016-2020) and DPN which aim to provide public housing which is affordable, sufficient and with quality to the citizens. Further, the outcome of this paper will provide a better understanding of the housing industry in Malaysia and its issues to public. The suggestions in this paper will not only benefit the stakeholders and meet the objectives under the $11^{\text {th }}$ Malaysia Plan and DPN, it will too help Malaysian Government to achieve the objectives as set out in the Sustainable Development Goals (SDGs) of the United Nations under the sub-heading 'mobilise sustainable cities and communities' and 'guarantee peace, justice and strong institutions'(World Top 20 Projects, 2019).

\section{Case Study 1: Abandoned Housing Project Taman Harmoni, Lot 82, Mukim Of Cheras, District Of Hulu Langat, Selangor, Malaysia.}

The first case study that this writing seeks to discuss is the abandoned housing project in Taman Harmoni, Lot 82, Mukim of Cheras, District of Hulu Langat, Selangor, Malaysia ('the said housing project'). The developer company of this housing project was K\&T Development Sdn. Bhd ('K\&T') (No. 065298-M). The said housing project consisted of Phase I and Phase II. Phase I had been fully completed with Certificate of Fitness for Occupation (' $\mathrm{CF}$ ') obtained and vacant possession delivered, but there was two years' late delivery of vacant possession for the units. On the other hand, Phase II had neither commenced nor been completed and was left abandoned 
by the defaulting developer (K\&T). This is the project under discussion in this writing (Phase II) (Majlis Perbandaran Kajang files number: MPKj PB/KM 2/41-99, MPKJ 6/P/14/93/PT 1).

\section{Summary of the Project}

The said housing project was divided into two phases, namely: Phase I comprising of singlestore-medium-cost terraced-houses and Phase II for the development of low-cost flat. The development of Phase I was completed, albeit there was a delay in the delivery of vacant possession of the units to purchasers, by the defaulting developer ('K\&T'). On the other hand, Phase II had not been commenced at all, except for the preliminary works. Phase II was deemed to be an abandoned housing project. The said housing project was a joint venture between K\&T, Setiausaha Kerajaan Negeri Selangor ('SUK (Incorporated)') (State government of Selangor agency), being the land proprietor and Permodalan Negeri Selangor Berhad ('PNSB') (state government of Selangor agency). The major ground causing the abandonment of the project was the financial issues faced by $K \& T$ due to its inadequate experience and expertise. The sale prices for the units were also unsuitable compared to the costs of construction costs emanating from additional earth and piling works. Fortunately, the project was rehabilitated by SUK (Incorporated) being the land proprietor, through their project manager, PNSB, until full completion.

Although the rehabilitation was at loss for PNSB and SUK (Incorporated), it was nonetheless proceeded with, on the reason that this project was for the social welfare of the low-income group. However, the rehabilitation undertaken was not without troubles. Among the issues the rehabilitating developer faced were the civil suit commenced by K\&T against the rehabilitating parties, and the problem of obtaining the approval from Syarikat Bekalan Air Selangor Sdn. Bhd. (SYABAS), being the water supply authority. On part of the purchasers, the grievances that they suffered were the inability to reside the purported units on time, having to pay other costs such as rent and their failure to get any late delivery compensation from K\&T. K\&T was wound up on the application of a contractor on 18 June 2004, at the High Court of Malaya at Shah Alam (Majlis Perbandaran Kajang files number: MPKj PB/KM 2/41-99, MPKJ 6/P/14/93/PT 1; Majlis Daerah Hulu Langat file numbers: MDHL 6P/14/93; Permodalan Negeri Selangor Berhad file number: PNSB 2/72 Jld.13 \& 14).

\section{Analysis of the Building Laws}

The developer and PNSB (the rehabilitating party) also faced a problem of uncertainty and variations of the conditions and requirements for the grant of Certificate of Fitness for Occupation (' $\mathrm{CF}$ ') in the approved plans, made by the technical agencies either in the middle of the housing development or after it, causing difficulties to the developer and PNSB and this had indirectly caused the abandonment. For example, Jabatan Bekalan Air ('JBA')(the water authority) initially required the water supply tank to be provided on the roof of the flat's buildings. However, later JBA varied the condition, by prescribing that the developer should provide a separate water tank building tower, one tank for watershed and a water booster pump house. This variation had directly caused substantial costs to the developer (A.K. Aznor, personal communication, November 6, 2006).

Similarly, Perbadanan Urus Air Selangor (PUAS) and later Syarikat Bekalan Air Selangor Sdn. Bhd. (SYABAS)(water supplier contractor in Selangor) also imposed the provision of a separate elevated water tank on PNSB. However, with the intervention by the Menteri Besar of Selangor (Chief Minister of Selangor), SYABAS finally agreed to waive this condition. 
Consequently, PNSB had to provide a groundwater tank with booster pumps system for supplying water to the low-cost flats from the water tank at the adjacent Taman Harmoni Indah (Permodalan Negeri Selangor file number: PNSB 2/72 Jld.14).

There is no provision in the SDBA or the UBBL which can provide a solution to the above problem, i.e. to ensure that there will be no variation in the earlier conditions prescribed in the the approved plans at the outset of the development for the project and to get CF. Alternatively, the technical agencies and the local authority, as the case may be, should bear the costs for effecting the variations required in order to get the $\mathrm{CF}$. The problem of uncertainty in the conditions for the $\mathrm{CF}$, i.e. the conditions for getting the $\mathrm{CF}$ in the approved plans were different from the much later requirements, had contributed to the abandonment of the project during the period when the project was undertaken by K\&T (the defaulting developer), due to insufficient funds to fulfil the changing requirements.

Aggravating the above problem, section 95(2) of the SDBA protects the State Authority and the local authority against any action whatsoever for any breach of duty and/or negligence in the course of carrying out their works as prescribed in the SDBA (Majlis Perbandaran Ampang Jaya v Steven Phoa Cheng Loon \& Ors [2006] 2 MLJ 389 (Federal Court)). Thus, again there is no remedy for the aggrieved developers or purchasers against these parties. However, there is no corresponding legal provision in the TCPA which purportedly protects the State Authority and the local planning authority if they are negligent or have breached the statutory or legal duty.

Following this, it is opined, if their decisions relating to planning matters (not being street, drainage and building matters) have unreasonably been made, or as the result of negligence or in breach of certain legal or statutory duties, then, their acts are actionable. However, the legal action is subject to the Public Authorities Protection Act 1948 (Act 198) (revised 1978), for instance, according to section 2(a) of this Act, the legal action must be initiated within three years from the default of that authority.

There is also no mandatory legal provision requiring the local authority or the technical agencies to implement reasonable and sufficient supervision, verification and inspection throughout construction and rehabilitation in respect of the building and other development works. Sections 70D and 70(22) of the SDBA and by-law 25(4) of the UBBL prescribe a duty on the local authority to undertake inspection, but this is not mandatory. Due to this, the developer may have carried out the project, not according to the law (the SDBA, Act 118 and Uniform Building By-Laws 1984. (GN.5178/84) ('UBBL'), to the detriment of the purchasers' interests.

Further, the new section 70(20) of the SDBA and the new by-law 25(1) of the UBBL prescribing the duty of the Principal Submitting Person (PSP) to issue a Certificate of Completion and Compliance ('CCC'), without reasonable and sufficient verification, supervision and inspection of the local authority and the technical agencies, may worsen the problem. This may happen if the PSP and the developer carry out sub-standard works and dishonestly issue false CCCs and progressive claims for the release of the purchasers' money from the end-financiers.

It should be noted that even the new Forms G1 to G21 of the UBBL do not require any reasonable and sufficient supervision, inspection and verification from the local authority and the technical agencies. These Forms G1--G21 have been inserted pursuant to by-law 26(c) of the Selangor Uniform Building By-Laws (Amendment) 2007 [Sel.P.U.9], enforced from 12 April 2007. Pursuant to some of these forms, at certain stages of construction, some technical 
agencies and the local authority are required to confirm that such a particular stage of construction has been duly carried out. For instance, Form G13 (Stage Certification: External Water Supply System) requires a letter of confirmation from the Water Authority, Form G 14 (Stage Certification: Sewerage Reticulation) and Form G 15 (Stage Construction: Sewerage Treatment Plant) require a letter of clearance from the Department of Sewerage Services (JPP)/Indah Water Consortium (IWK), Form G 16 (Stage Certification: External Electrical Supply System) requires a letter of confirmation from TNB and Form G 17 (Stage Certification: Road and Drain) requires a letter of confirmation from the relevant local authority/Public Works Department. However, the requirement is only being a letter of confirmation or letter of clearance from these agencies. There is no mandatory provision, in the SDBA and the UBBL (including the UBBL) requiring reasonable and sufficient inspection, supervision and verification by the relevant technical agencies or local authority over the construction works during and after the course of undertaking the important stages of construction and works, that the works done have duly complied with the law and the required standards.

The author finds that, based on the above case study, the local authority (Majlis Perbandaran Kajang) and the technical agencies (Public Works Department (JKR), Fire and Rescue Department (BOMBA), Health Department (PK), water authority (JBAS), District/Land Office of Hulu Langat, Department of Water and Drainage (JPS), electric authority (LLN) (former TNB), and telecommunication contractor (TM Berhad)) only conducted two (2) cross-checks, inspections, site visits and verifications. Firstly, after the applicant developer submitted the required plans and specifications for getting the approved building/infrastructure/earthwork plans. Secondly, after the applicant rehabilitating party (PNSB) lodged the application for CF with the local authority. There were no cross-checks, inspections, site visits and verifications made by the local authority and the technical agencies, over all the progressive construction works and materials used during the development and rehabilitation. This failure could lead to the possibility of false or unreasonable certifications made by the qualified persons (professional architect, professional engineer or building draughtsman), which may result in the completed building being unfit or being not following the requirements of the law, especially the UBBL, Housing Development (Control \& Licensing) Act 1966 (Act 118) and SDBA. This is so, as there is no mandatory legal and statutory provision requiring the local authority and the technical agencies to carry out such a cross-check, supervision and inspection over the progressive construction works throughout the construction stages.

Likewise, even though the requirements of By-law 22(1)(2) (Form B--Notice of Commencement/Resumption of Building Operations), By-law 23 (Form C--Notice of Completion of Setting Out) and By-law 24(Form D--Notice of Completion of Excavation for Foundation) of the UBBL, had been generally complied with and certified by the principal submitting person (PSP) or the qualified person, these notices or information as conveyed by the submitting persons or qualified person, insofar as the UBBL is concerned, had not been verified nor were the purported works inspected by the local authority to ensure the standard and quality of the works.

Based on the author's legal observations of the above project, the local authority/building authority (MPKj/MDHL) failed to carry out the requirements set out by section $70 \mathrm{D}(1)$ and section $70 \mathrm{~B}(2)$ of the SDBA viz, to inspect the site of the building, to detect defect and deformation in the structure of the building. This duty will be triggered upon the local authority when the local authority reasonably suspects there is a defect, deformation or deterioration in the structure of a building under erection which may likely result in the failure of the building; 
the local authority may issue to the owner of the building an order to review the safety and stability of the building; the foundation of the building; and the surroundings on which the erection of building is in progress. It is submitted that, due to the long period of abandonment before rehabilitation, the local authority should have been reasonably suspected that there might be a possible defect, deformation or deterioration in the structure of a building, which might likely result in the failure of the building. The failure of the local authority/building authority to carry out such statutory requirement might lead to the failure of the building, which had been abandoned and incomplete for a certain duration, before the abandoned building is subject to rehabilitation. It is noteworthy that there is no definition in the SDBA and the UBBL on the meaning of 'failure of building'. Neither is there in the case law and the UBBL. However, according to section 71 of the SDBA - 'the failure of building or part of building and failure of the earthworks or part of the earthworks' is due to-'a) misconstruction or lack of proper supervision during construction; b) misdesign or miscalculation; or c) misuse'. The author submits, when construction of building is abandoned, the building can also be said as being a failed building.

The qualified person also failed to give the written notice, pursuant to By-law 24 of the UBBL, to the local authority, informing the nature of the soil conditions (slime soils) as affected by the land site excavations affronting the design requirements and not in accord with the requirements of the UBBL. In other words, the soil condition of the project in this case study 1 was not fit and not suitable for development of buildings on it and did not comply with the requirements of the UBBL, for instance, according to the structural and constructional requirements (By-laws 53 to by-law 132).

Further, PNSB, as the rehabilitating party, had also failed to serve the 4(four) days' notice in writing of their intention to commence or to resume the rehabilitation, works to $\mathrm{MPKj}$, as required by section 70(9)(a)(b) of the SDBA. K\&T (the developer) and PNSB (the rehabilitating party) also failed to serve the three (3) months periodic progress reports to the local authority as prescribed in the conditions for the approved building plan (Majlis Daerah Hulu Langat file numbers: MDHL 6P/14/93; Majlis Perbandaran Kajang file number: MPKj 6P/25/2002; Permodalan Negeri Selangor Berhad file number: PNSB 2/72 Jld.13).

The qualified persons (architect, registered building draughtsman or engineer), during the early part of development and rehabilitation too, failed to report, explain and state the remedial action for the abandonment and failure of the buildings, as required by By-law 258(1)(2) of the UBBL to the local authority. If the qualified person fails to comply with by-law 258(1)(2)(3) of the UBBL (duty to report and explain the failure of the building and its causes), he shall be guilty of an offence, under by-law 258(4) (read together with section 71 of the SDBA). Thus, in abandoned housing project, the qualified person shall have to report to the local authority and state the remedial action, according to by-law 258(1)(2) or (3) of the UBBL. Pursuant to section 71 of the SDBA, the person who is responsible for such failure due to the above factors, shall be liable on conviction to a fine of not exceeding five hundred thousand ringgit (MYR $500,000.00$ - USD 117302.10) or to imprisonment for a term not exceeding ten years or to both. See also by-law $25(4)(5)(6)(7)(8)(9)(10)(11)(12)$ and (13) of the UBBL, in respect of, among other things, the duty of the PSP to rectify the failure of the building and the right of the Local Authority to direct the PSP to withhold the issuance of CCC, if there is a failure of the building.

Despite the failure of the qualified persons to comply with By-law 258(1)(2), the local authority (MPKj) too failed to invoke and enforce the requirements of By-law 258(3)(4) of the UBBL and section 71 of the SDBA against the qualified persons. 
In the above project, even though the application for CF having been made, certified by the qualified persons as to, inter alia, the provision of water following By-law 25(1)(b) of the UBBL and even after the complete CF (not partial or temporary CF) had been obtained, no water had been provided to the flats. This is because, there was an instruction from Majlis Tindakan Ekonomi Selangor (MTES) (Selangor Economic Action Committee) to MPKj to issue the full $\mathrm{CF}$, even though no water supply had been provided, for enabling the delivery of vacant possession of the completed units to purchasers.

Despite these contraventions, there was no legal action/enforcement taken by the local authority against the perpetrators. It is observed that these phenomena were due to the lack of staff in the local authority office. Most of the staff were contract staff, with the possibility they might show insufficient responsibility over the works done and lackadaisical attitude and insufficient legal and technical knowledge. This is because, based on the observation of the author, the staff who conducted the site visits and verifications over the site projects, were mostly certificate or diploma holders, not degree holders or their knowledge might not be updated and being current to the current practices in the industry. Besides, as observed by the author, there were insufficient office facilities on part of MPKj (such as computers, chairs, tables, air-conditioners, typing machines, sufficient computer hardware and software, congested and small size offices and insufficient administrative and meeting rooms especially in the Department of Town Planning and Department of Building). Nevertheless, even though there is negligence or breach of statutory duties on part of the local authority, they are still protected by section 95(2) of the SDBA (Steven Phoa Cheng Loon \& Ors v Highland Properties Sdn Bhd \& Ors [2000] 4 MLJ 200; [2000] 3 AMR 3567 (High Court of Malaya at Kuala Lumpur); Majlis Perbandaran Ampang Jaya v. Steven Phoa Cheng Loon \& Ors [2006] 2 CLJ 1; [2006] 2 MLJ 389 (Federal Court)). This legal provision could indirectly stimulate developers to neglect and breach their statutory duties, as there could be no enforcement of the penal provisions as provided in the SDBA and UBBL against them, for instance by way of corruption.

Finally, the establishment of OSC may be insufficient to settle the above problems falling under the approval of plans' stages.

\section{Case Study 2: Abandoned Housing Project Taman Lingkaran Nur, Km 21, Jalan Cheras-Kajang, Mukim Of Cheras, District Of Hulu Langat, Selangor Malaysia.}

The second case study is the abandoned housing project in Taman Lingkaran Nur, KM 21, Jalan Cheras-Kajang, P.T No. 6443, HS (D) 16848, Mukim of Cheras, District of Hulu Langat, Selangor ('the said project'). The said project was commenced in 1988 by a developer, named Saktimuna Sdn. Bhd. ('Saktimuna') on a land which had been alienated from the State Government of Selangor (Jabatan Perancangan Bandar dan Desa file number: PTD. U.L1/2/364-Semt). At the outset, this purported development project was divided into three (3) phases: Phase 1, Phase 2 and Phase 3. Only a portion of Phase 1, i.e. Phase 1A (Phase 1 was divided into Phases 1A and 1B) had been fully developed. However, this Phase was in the middle of development, abandoned. Its construction terminated at the stage of $60 \%$ completion. Phases $1 \mathrm{~A}, 1 \mathrm{~B}$ and 2 are the subject matters of analysis in this paper.

\section{Summary of The Project}


The said project was a result of a privatisation project between Saktimuna Sdn. Bhd. (the defaulting developer) and the Selangor State Government. The latter was the proprietor of the land, who later alienated the land to the defaulting developer to develop it into a housing project subject to certain conditions. However, in the course of the development of the project, the project stopped and was later abandoned. This was because the defaulting developer (Saktimuna) faced severe financial problems due to insufficient revenues through sales and their failure to meet the development construction costs. This problem persisted from 1992 until early 2000 (Syarikat Perumahan Negara Berhad file number: SPNB/Taman Lingkaran Nur 4).

After the project was abandoned, it was subsequently taken over by one Syarikat Lingkaran Nur Sdn. Bhd. ('SLN'). SLN attempted to become the rehabilitating party with the consent of the State Government of Selangor and the defaulting developer. Unfortunately, SLN was also unable to complete the project due to financial issues (Ministry of Housing and Local Government file number: JKPMT/08/824/4275 Jld. 4).

On the numerous appeals from the aggrieved purchasers and instruction of MHLG, Syarikat Perumahan Negara Berhad ('SPNB') had taken over part of the project, i.e., Phase 1A, from SLN. The taking over of the abandoned housing project was with the consent of the Selangor State Government and Saktimuna. Being a Government-linked company (GLC), SPNB managed to procure funds from the Ministry of Finance ('MOF') to rehabilitate the abandoned project. At last, the rehabilitation succeeded. However, this rescue package was considered as a government social duty, in that, the available money in the hands of the end-financiers was inadequate to cover the rehabilitation costs. MOF had to add up new funds to guarantee the completion of the rehabilitation. In the course of the rehabilitation, there were several issues faced by SPNB. One of them was the refusal of certain purchasers to give consent to SPNB to implement the purported rehabilitation works. Thus, not all the units in Phase 1A were rehabilitated and got CFs. The remaining phases (Phases 1B and 2) have as yet to be revived. These phases are still in the course of negotiation for rehabilitation, both by Saktimuna, the Official Receiver ('OR') (being the Kuala Lumpur Department of Insolvency ('KL JIM')) and the new chargee (Idaman Wajib Sdn. Bhd). While Phase 3 of the project had been completed through a joint venture between Tanming Sdn. Bhd and SLN. This Phase 3 is now a part of new project called Taman Cheras Idaman (Ministry of Housing and Local Government file number: JKPMT/08/824/4275 Jld. 4).

The developer company (Saktimuna) was liquidated on 11 March 2005 on the winding-up application of the Inland Revenue Board (Lembaga Hasil Dalam Negeri - 'LHDN') for its failure to settle off the unpaid corporate tax debts to LHDN. On 11 March 2005, the OR (KL JIM) was appointed as the provisional liquidator for the wound-up developer company. Later, the OR was also appointed as the liquidator on 12 May 2009 (Insolvency Department file number: JIM(WP)14/2005/A).

Phases 1B and 2 at Taman Lingkaran Nur were vested in Singesinga Sdn. Bhd. ('Singesinga') by the chargee Messrs CIMB Bank Berhad ('CIMB') to settle Saktimuna's outstanding debts to the chargee lender (CIMB), vide a Court's vesting order. However, this had not been made known to the OR (as the liquidator), and the OR too had not provided the parties with any consent for such a legal action (application to vest the rights of CIMB in Phases $1 \mathrm{~A}$ and B to Sinesinga to settle off the debts of Saktimuna to CIMB) (Insolvency Department file number: JIM(WP)14/2005/A). 
As of now, there is no plan to rehabilitate Phase 1B. However, in respect of Phase 2, there is an interested buyer to buy the project site land to settle the redemption sum as stipulated by the new chargee (Sinesinga). This interested purchaser is Idaman Wajib Sdn. Bhd ('IWSB'). In this project (Phases 1A, 1B and 2), the OR as the liquidator, did not revive the project, but he only streamlined the stakeholders. Until today, there was no rehabilitation of the housing development project for Phases 1B and 2 at Taman Lingkaran Nur (Insolvency Department file number: JIM(WP)14/2005/A).

\section{Analysis of the Building Laws}

There was no information as to whether SPNB, in the rehabilitation of Taman Lingkaran Nur, had applied for an extension of the expired plans (Infrastructure, Building and Earthwork) based on the file review. However, there were numerous meetings conducted on the requests of SUK, MHLG and Lembaga Perumahan dan Hartanah Selangor ('LPHS') to ensure the completion of the rehabilitation. One of the matters discussed in the meetings was the conditions imposed by $\mathrm{MPKj} / \mathrm{MDHL}$ and the technical agencies for obtaining the required CF, which SPNB had to comply with (Syarikat Perumahan Negara Berhad files number: SPNB/Taman Lingkaran Nur 6, MPKj 6/P/86/87 and SPNB/Taman Lingkaran Nur 4). SPNB had also applied for certain exemptions from MPKj/MDHL and the technical agencies in regard to certain CF's requirements supported by KPKT's letter for reducing rehabilitation costs but not all the applications were allowed (Ministry of Housing and Local Government file number KPKT/08/824/4275 Jld. 6). An example of the rejected application was the request from SPNB to use the constructed road provided by the previous developer. $\mathrm{MPKj} / \mathrm{MDHL}$ still required SPNB to provide the internal structure for roads which had a 'crusher run' with the thickness of $300 \mathrm{~mm}$ including the 'wearing course' layer (Ministry of Housing and Local Government files number KPKT/08/824/4275 Jld. 6 and in MPKj 6P/86/87). Other requested matters which were rejected by MPKj/MDHL and JPP from SPNB were--to use the infrastructure works (internal road works, reconstruction of sewer line, constructed manhole and the incomplete manhole), and the Sewage Treatment Plant (STP) as done by the previous developers (Ministry of Housing and Local Government file number KPKT/08/824/4275 Jld. 6). This was because these works were not entirely made in accordance with the requirements of MPKj/MDHL and JPP (Ministry of Housing and Local Government file number KPKT/08/824/4275 Jld. 6).

In author's observation of the above project, MPKj/MDHL (local authority) failed to carry out the requirements set out by section 70B (1) and (2) of the SDBA, i.e., a failure to carry out any visual inspection on the site of the building (in respect of the changes to the features, topography of the project site land or the neighbouring area brought about by the construction of the building etc.) and a failure to have reasonably suspected any defect and deformation in the structure of the building, which might lead to the failure of the building and which they might have been suspected, as a result of a long abandonment of the project and during rehabilitation, pursuant to section $70 \mathrm{~B}(2)$ of the SDBA.

The rehabilitating parties (SLN and SPNB) failed to serve the written 4(four) days' notice of their intentions to resume the purported rehabilitation works to $\mathrm{MPKj}$, pursuant to section 70(9)(a)(b) of the SDBA. The developer and the rehabilitating parties (SLN and SPNB) too failed to submit the three (3) months progress reports to the local planning authority as required in the building plan's approvals (Majlis Daerah Hulu Langat file number: MDHL 6/P/86/87).

The qualified persons (the registered building draughtsman, professional architect, or professional engineer) of the project (during initial development and rehabilitation) too failed 
to report, explain and state the remedial action for the abandonment and failure of the buildings due to the long abandonment, pursuant to By-law 258(1) and (2) of the Uniform Building ByLaws 1984 (GN.5178/84) ('UBBL')/UBBL to the local authority. Similarly, the local authority $(\mathrm{MPKj})$ in this case study also failed to adhere to the requirements of by-law 258(3) of the UBBL/UBBL/Kedah UBBL and section 70B(2) of the SDBA.

Despite these contraventions, there was no legal action/enforcement taken by the local authority against the perpetrators. In the observation of the author, these phenomena were due to the lack of staff and other human resource problems (such as ineffective administration etc.), as well as knowledge and administrative logistics weaknesses on part of the local authority as illustrated in the previous case study one.

The change of certain conditions made by certain technical agencies in the middle of the development again had costed substantial additional money on part of the rehabilitating parties (SLN and SPNB) which affected the smooth progress of the purported rehabilitation.

Thus, it seems that the conditions set were not certain and might be changed later right in the middle of the development and rehabilitation to the detriment of the rehabilitating parties. SLN faced this problem in the course of rehabilitation from certain technical agencies-Department of Sewerage Service (JPP), Department of Water Supply (JBA) and electric provider (TNB). However, this problem was lessened when the rehabilitation of the project was undertaken by SPNB, being the Government-linked company (GLC) who received support from KPKT and Ministry of Finance ('MOF'). As a result, SPNB obtained certain exemptions from conditions required by some technical agencies (Ministry of Housing and Local Government file number: KPKT/08/824/4275 Jld.6).

Further, in the course of rehabilitation, there are no legal and statutory conditions requiring the local authority, KPKT and the technical agencies to cross-check, inspect, supervise and verify that all the works done were in pursuance of the requirements under the law (the SDBA, UBBL, and Act 118) and the standard practice in building development. Similar to the findings in the first case study above, the author finds that the local authority (MPKj) and the technical agencies (JKR, BOMBA, PK, JBAS, District/Land Office of Hulu Langat, JPS, Lembaga Letrik Negara as the electric supplier (LLN)(former TNB) and telecommunication provider - TM Berhad) only did two (2) cross-checks, supervisions, inspections, site visits and verification. Firstly, after the applicant developer submitted the required plans and specifications for approval of plans. Secondly, after the application for CF was lodged. Thus, there is a gap in the course of the housing development and rehabilitation for carrying out the necessary crosschecks, supervisions, inspections, and verification by the local authority and the technical agencies, in respect of all the building works done and building materials used. This failure may precipitate possible certification abuse by the qualified persons and may render the completed building unfit and not in accordance with the requirements of the law. This was so, as there is no legal and statutory provision in Act 118, UBBL and SDBA, requiring these parties to carry out supervision or at least inspection in the course of the development and the rehabilitation.

Akin to the first case study, under the instant case study, even though the requirements of Bylaw 22(1)(2)(Notice of commencement/resumption of building operations), By-law 23 (Notice of completion of setting out), and By-law 24 (Notice of completion of excavation for foundation) of the UBBL had been generally complied with by the defaulting developer and the rehabilitating parties, as well as the works done had been certified by the submitting or 
qualified person, the local authority still did not duly verify the information so contained in the notices. This is because there is no legal provision imposing a duty, on the local authority, to verify such information.

Finally, likewise as explained before in the first case study and the author repeats that the establishment of One Stop Centre (OSC) may be inadequate to settle the above problems falling under the planning permission and approval of plans' stages.

\section{Findings}

The findings, based on the above case-studies, highlight the following problems:

1) The problem of uncertainty and variations of the conditions and requirements for the issuance of Certificate of Fitness for Occupation ('CF') in the approved relevant approved plans, made by the local authority (building authority) either in the middle of the housing development or after it, causing difficulties to the developers and the rehabilitating parties indirectly leading to abandonment of the project.

2) Failure to comply with certain provisions in the Uniform Building By-laws 1984 (GN 5178/84) (UBBL) by the defaulting developers and the rehabilitating parties;

3) Insufficient enforcement and implementation of the UBBL by the local authority;

4) Problem emanating from section 95(2) of the SDBA to the effect of absolving the liabilities of the State Authority and the local authority in the event of negligence and non-fulfilment of statutory and administrative duties such as failure to carry out the requisite inspection and supervision;

5) No mandatory legal provision requiring the local authority or the technical agencies to carry out supervision, verification and inspection throughout construction and rehabilitation in respect of the building and other works done in order to ensure good quality work; and,

6) Lack of staff and professional human resource, shortage of training, inadequate legal and technical knowledge of the staff and insufficient administrative logistics in the local authority office, which have led to the inefficient administration and enforcement of the law.

\section{Suggestions and Conclusion}

The author contends that the approved plans (including building plan) and the conditions imposed by the local authority or the technical agencies, should be irrevocable for the issuance of certificate of completion and compliance(CCC). If later, there is any variation in the plans or conditions for the issuance of the said certificate, requested by the local authority or the technical agencies, as the case may be, that local authority or technical agencies should make good of any damage suffered by the developers as the result of such changes and variations. Thus this suggestion should be incorporated into the provision of the SDBA.

In respect of the human resource, logistics issues and inefficient administration, the author proposes that administrative revamps, adequate priority and monetary provisions should be provided by the Federal and State Governments to ensure the efficiency of the local authority and the technical agencies administration.

Apart from the above, the provision of section 95(3) SDBA which protects the local authority and the state authority against any negligence and non-fulfilment of statutory and administrative duties such as failure to carry out the requisite inspection and supervision should be amended 
6-8 August 2021

Budapest, Hungary

and/or repealed to ensure that these authorities could carry out their respective duties and responsibilities ineffectual and justiciable manner.

\section{Acknowledgment}

The author would like to thank the Malaysian Ministry of Higher Education (MOHE) for providing the author with a Research Grant - Fundamental Research Grant Scheme (FRGS) S/O Code 14175/Research ID 5007197 which has enabled the author to carry out the research activities and write this paper.

\section{References}

Abdullah, AA, \& Abdul Rahman, H. (2012). "Identification of relevant risks in abandoned housing projects in Malaysia: a qualitative study". Procedia - Social and Behavioral Sciences 62, pp. $1281-1285$.

Abdul-Rahman, H., Alashwal, A.M., Ayub, M, Abdullah, A.A. (2013). "Abandoned Housing Projects in Malaysia: Pressing Issues During the Rehabilitation Process". ArchNet-IJAR: International Journal of Architectural Research, vol. 7, issue 1, pp. 65-73.

Abdul Razak, D. (2016). "Determinants Of Abandoned Housing Projects In Malaysia". International Journal of Islamic Business Ethics (IJIBE), Volume 1, Number 1, 2016, pp. $1-12$.

Abdul Razak, D., Mohammed, M.O., \& \& Md. Tarique, K. (2015). "Abandoned Housing Projects in Malaysia and the Prospect of DP: An Overview". Procedia Economics and Finance, Volume 31, 813-822.

Arab-Malaysian Finance Bhd v Steven Phoa Cheng Loon 7 Ors and other appeals [2003] 1 MLJ 567 (Court of Appeal at Kuala Lumpur).

Aw Yong Wai Choo \& Ors v. Arief Trading Sdn. Bhd \& Anor [1992] 1 MLJ 166).

Bernama. (2019, 8 March). Highland Towers to be demolished latest by June, says Zuraida [online] New Straits Times. Available: https://www.nst.com.my/news/nation/2019/03/467400/highland-towers-be-demolishedlatest-june-says-zuraida.

Division of Supervision and Enforcement, Ministry of Housing and Local Government. (1999). Senarai Projek Perumahan Swasta Terbengkalai Tahun 1999. Kuala Lumpur: Author.

Dobinson, I., \& Johns, F. (2007). Qualitative Legal Research. In Research Method for Law. In Research Methods for Law. (McConville, M., \& Chui, W. Hong Eds.). Edinburgh: Edinburgh University Press.

Environmental Quality (Prescribed Activities) (Environmental Impact Assessment) Order 1987 (PU (A) 362/87).

Housing Development (Control \& Licensing) Act 1966 (Act 118).

Khalid, M.S. (2010). Abandoned housing development the Malaysian experience. (Unpublished doctoral dissertation). Heriot-Watt University, Edinburgh, Scotland, United Kingdom. 
6-8 August 2021

Budapest, Hungary

Law Insider. (June 9, 2012). Definition of building law. [Online]. Available: https://www.lawinsider.com/dictionary/building-law.

Law Insider. (June 2, 2020). Definition of building law. [Online]. Available: https://www.lawinsider.com/dictionary/building-law.

Letters, circulars and undocumented materials of Insolvency Department file number: JIM(WP)14/2005/A.

Letters, circulars and undocumented materials of Jabatan Perancangan Bandar dan Desa file number PTD. U.L1/2/364-Semt.

Letters, circulars and undocumented materials of Majlis Daerah Hulu Langat file numbers: MDHL 6P/14/93.

Letters, circulars and undocumented materials of Majlis Daerah Hulu Langat 6/P/86/87.

Letters, circulars and undocumented materials of Majlis Perbandaran Kajang file number: MPKj 6P/25/2002.

Letters, circulars and undocumented materials of Ministry of Housing and Local Government in file number: File numbers: KPKT/08/824/2605.

Letters, circulars and undocumented materials of Ministry of Housing and Local Government in file number: KPKT/08/824/7347-I.

Letters, circulars and undocumented materials of Ministry of Housing and Local Government in file number: KPKT/08/824/2732-01.

Letters, circulars and undocumented materials of Ministry of Housing and Local Government in file number: KPKT/08/824/1843.

Letters, circulars and undocumented materials of Ministry of Housing and Local Government in file number: KPKT/08/824/63 97-1, Jld 2.

Letters, circulars and undocumented materials of Ministry of Housing and Local Government in file number: KPKT/BL/19/6397-I.

Letters, circulars and undocumented materials of Ministry of Housing and Local Government in file number: KPKT/08/824/4285-1.

Letters, circulars and undocumented materials of Ministry of Housing and Local Government in file number: KPKT/08/824/3947-5.

Letters, circulars and undocumented materials of Ministry of Housing and Local Government in file number: KPKT/08/824/6037-1.

Letters, circulars and undocumented materials of Ministry of Housing and Local Government in file number: KPKT/08/824/365,

Letters, circulars and undocumented materials of Ministry of Housing and Local Government in file number: KPKT/08/824/1910.

Letters, circulars and undocumented materials of Ministry of Housing and Local Government in file number: KPKT/BL/19/1171-1.

Letters, circulars and undocumented materials of Ministry of Housing and Local Government in file number: KPKT/(05)/1910. 
6-8 August 2021

Budapest, Hungary

Letters, circulars and undocumented materials of Ministry of Housing and Local Government in file number: KPKT/08/824//337.

Letters, circulars and undocumented materials of Ministry of Housing and Local Government in file number: KPKT/08/824/153/E.

Letters, circulars and undocumented materials of Ministry of Housing and Local Government in file number: KPKT/08/824/2605.

Letters, circulars and undocumented materials of Ministry of Housing and Local Government in file number: KPKT/08/824/365.

Letters, circulars and undocumented materials of Ministry of Housing and Local Government in file number: KPKT/08/824/1910.

Letters, circulars and undocumented materials of Ministry of Housing and Local Government in file number: KPKT/BL/19/1171-1.

Letters, circulars and undocumented materials of Ministry of Housing and Local Government in file number: $\mathrm{KPKT} /(05) / 1910$.

Letters, circulars and undocumented materials of Ministry of Housing and Local Government in file number: KPKT/08/824//337.

Letters, circulars and undocumented materials of Ministry of Housing and Local Government in file number: KPKT/08/824/153/E.

Letters, circulars and undocumented materials of Ministry of Housing and Local Government in file number: KPKT/08/824/2605.

Letters, circulars and undocumented materials of Ministry of Housing and Local Government in file number: KPKT/08/824//337.

Letters, circulars and undocumented materials of Ministry of Housing and Local Government in file number: KPKT/08/824/2605.

Letters, circulars and undocumented materials of Ministry of Housing and Local Government in file number: KPKT/08/824/7347-I.

Letters, circulars and undocumented materials of Ministry of Housing and Local Government in file number: KPKT/08/824/2732-01.

Letters, circulars and undocumented materials of Ministry of Housing and Local Government in file number: KPKT/08/824/1843.

Letters, circulars and undocumented materials of Ministry of Housing and Local Government file number: JKPMT/08/824/4275 Jld. 4).

Letters, circulars and undocumented materials of Ministry of Housing and Local Government file number KPKT/08/824/4275 Jld.6).

Letters, circulars and undocumented materials of Permodalan Negeri Selangor Berhad file number: PNSB 2/72 Jld. 13 \& 14.

Letters, circulars and undocumented materials of Syarikat Perumahan Negara Berhad file number SPNB/Taman Lingkaran Nur 4. 
Majlis Perbandaran Ampang Jaya v. Steven Phoa Cheng Loon \& Ors [2006] 2 CLJ 1; [2006] 2 MLJ 389 (Federal Court).

Majlis Perbandaran Pulau Pinang v. Syarikat Bekerjasama-sama Serbaguna Sungai Gelugor Dengan Tanggungan [1999] 3 MLJ 1 (High Court of Malaya at Penang).

Majlis Perbandaran Seberang Perai v. Tropiland Sdn. Bhd. [1996] 3 MLJ, 94 (Court of Appeal); [1996] 3 CLJ 837 (Court of Appeal).

Md Dahlan, N. H. (2014, B). Legal issues in the alienation of lands for housing development projects in Peninsular Malaysia: A case study of Kedah Darul Aman. (Research Project Report. Universiti Utara Malaysia). Sintok, Kedah, Malaysia: Universiti Utara Malaysia. School of Law.

Md Dahlan, NH (2011, A). Legal issues in the rehabilitation of abandoned housing projects. Sintok: UUM Press.

Md Dahlan, N. H. (2011, B). Comparative housing sale and purchase agreements under the Malaysia, Singapore and New South Wales housing laws. Sintok: UUM Press.

Md Dahlan, NH (2011, C). "Rehabilitation of abandoned housing projects: A comparative analysis between the law and practice in Peninsular Malaysia and the Republic of Singapore". Commonwealth Law Bulletin, 37 (1), pp. 145-173.

Md Dahlan, NH (2011, D). "Legal Issues in the rehabilitation of abandoned housing projects of the liquidated housing-developer-companies in Peninsular Malaysia". European Journal of Social Sciences, 23 (3), pp. 392-408.

Md Dahlan, N. H. (2012, A). "Legal issues in the alienation of lands for housing development projects in Malaysia". Malayan Law Journal, 6, pp. xli-lxiii.

Md Dahlan, NH (2012, B). "Comparative legal analysis between the rehabilitations of the failed residential projects of the liquidated housing developer companies in Malaysia and the Republic of Singapore". Journal for Global Business Advancement, 5 (2), pp. 126-149.

Md Dahlan, NH (2012, C). "Rehabilitation of abandoned housing projects of housing developer companies under receivership in Peninsular Malaysia: Some salient issues and suggestions”. The Law Review. Pp. 390-59.

Md Dahlan, N. H. (2016). "Alienation of land for housing development projects in Malaysia and New South Wales, Australia: A comparative legal analysis." Malayan Law Journal, 1. Pp. xliii-xxviii.

Md Dahlan, N. H., Mohamed Nafees, S, M. \&, Ahmad, M.H. (2019). A planning law perspective on abandoned housing projects in Malaysia. In Mashdurohatun, A, Wahyuningsih, A.E., Hussain, M.A., Abdul Rahim, A. (Eds.), Selected Legal Issues in Indonesia and Malaysia (pp. 98-117). Semarang, Indonesia: Unissula Press, Universitas Islam Sultan Agung.

Md Dahlan, N. H., Shuib, M.S., \& Mohd Noor, F. (2018). "Malaysian case law on issues of Islamic home finance Bay' Bithaman Al-Ajil (BBA): An Analysis". International Journal of Law, Government and Communication, 3 (13), pp. 1-20.

Md Dahlan, NH (2006). "Abandoned Housing Projects in Malaysia: A Legal Perspective". Malayan law journal, 6, pp. i-xxxv. 
6-8 August 2021

Budapest, Hungary

Md Dahlan, N.H. (2008a). "Projek perumahan terbengkalai dan pemulihan oleh "penerima dan pengurus”. Kanun: Jurnal Undang-Undang Malaysia, 20 (1), pp. 1-71.

Md Dahlan, NH (2009). Abandoned Housing Projects in Peninsular Malaysia: Legal and Regulatory Framework (Unpublished $\mathrm{PhD}$ in Law's Thesis). International Islamic University Malaysia, Gombak, Selangor, Malaysia.

Md Dahlan, NH (2009). "Are the statutory standard sale and purchase of house contracts in peninsular Malaysia compatible with Islamic law?" Malayan Law Journal, 5, pp. i--xxxiv.

Md Dahlan, NH (2018, A). "Commodity Murabahah Islamic Home Finance in Dealing with Abandoned Housing Projects in Malaysia: Features, Issues \& Prospects". International Journal of Education, Islamic Studies and Social Sciences Research, 3 (1(13)), pp. 1-11.

Md Dahlan, NH (2018, B). "Musharakah Al-Mutanaqisah Islamic home finance in dealing with abandoned housing projects in Malaysia: Features, issues, and prospects". International Journal of Education, Islamic Studies and Social Sciences Research, 3 (1(14)), pp. 1-13.

Md Dahlan, NH (2019, A). "Housing Development Account ('HDA') for Private Housing Developers in Peninsular Malaysia: Law and Legal Issues". Malayan Law Journal, 4, pp. xxxvii-lii

Md Dahlan, NH (2019, B). "Islamic home finance products vis-a-vis failed residential projects in Malaysia: reality, issues and prospects". Journal of Advanced Research in Dynamical \& Control Systems, 11 (8), pp. 261-264.

Md Dahlan, NH (2007, A). "Definition of 'abandoned housing project': A legal analysis". Malayan Law Journal, 5, pp. xxvii-lv.

Md Dahlan, NH (2007, B). "Rehabilitation of abandoned housing project Peninsular Malaysia by a purchasers' voluntary scheme: A case study". Malayan Law Journal, pp. clvii-cxcvii

Md Dahlan, NH (2007, C). "Rehabilitation of abandoned housing project: Experience of an abandoned housing developer through the help of a government agency". Malayan Law Journal, 1, pp. 1xxxiv-cxxvi.

Md Dahlan, NH (2013). "Scheme of arrangement (SOA) in the rehabilitation of abandoned housing projects: A case study Of Malaysia”. Asian Studies International Journal, 1 (1), pp. 36-53.

Md Dahlan, NH (2014, A). "Extent of liability and responsibility of the state authority in the alienation of lands for housing development projects in Malaysia: A case study of abandoned housing projects". Malayan Law Journal, 2. Pp. xvii-xliii.

Md Dahlan, NH, \& Masum, A. (2014, B). "Feasibility of corporate voluntary arrangement ("CVA") in solving insolvency issues in abandoned housing projects: a comparative legal analysis between Malaysia and the United Kingdom". The Law Review, pp. 546-572.

Md Dahlan, NH $(2014$, C). "Issues in the rehabilitation of failed residential projects in Malaysia: Clash between the interests of purchasers and secured creditor chargee". Journal for Global Business Advancement, 7 (2), pp. 139-150.

Md Dahlan, NH (2014, D). "Issues of Khiyar (option) in housing agreements in Peninsular Malaysia". Malayan Law Journal, 1, pp. 1-lxxvii. 
6-8 August 2021

Budapest, Hungary

Md Dahlan, NH (2014, E). Corporate insolvency laws in abandoned housing projects: Issues and prospects. Sintok: UUM Press.

Md Dahlan, NH (2015, A). "Issues in the Malaysian statutory housing agreements (Schedules G, H, I And J):'Defect liability period". Current Law Journal, pp. 9-25.

Md Dahlan, NH (2015, B). "Issues in the statutory housing sale agreements in Peninsular Malaysia: A case study of abandoned housing projects". The Law Review, pp. 377-397.

Md Dahlan, NH (2015, C). "Comparative legal analysis on the viability of judicial management on insolvent residential developer companies in Malaysia, The Republic of Singapore and The United Kingdom". Malayan Law Journal, 2 (20), pp. xx-xliii.

Md Dahlan, NH, \& Abdullah, H.H., \&, Warokka, A. (2010). Rehabilitation of abandoned housing projects in Peninsular Malaysia: Lessons for housing entrepreneurs. Advances in Global Business Research, 7 (1), pp. 1-13.

Md Dahlan, NH, \& Masum, A. (2014, A). "Abandoned housing projects in Malaysia: Legal issues relating to the housing developer's licence". The Law Review, pp. 573-586.

Md Dahlan, NH, \& Syed Abdul Kader, S.Z. (2010). "Shariah and legal issues in the bay' bithaman-al-ajil (BBA): A viewpoint”. Malayan Law Journal, 6, pp. lxxv -cxiii.

Md Dahlan, NH, \&, Syed Abdul Kader, S.Z. (2012). "Rehabilitation of abandoned housing projects of liquidated housing-developer-companies: A comparative legal analysis between the position in Malaysia and in the United Kingdom". Malayan Law Journal, 4, cxviii-cliv.

Md Dahlan, N.H., Abdul Jalil, A.Z., Zainol, Z., \& Maamor, S. (2016). "The Shariah Advisory Council in the Malaysian Islamic financial institutions: features and legal issues". Journal for Global Business Advancement, 9 (3), 284-298.

Md Dahlan, NH, Mohd Noor, F., \& Shuib, M.S. (2017a). "Is Malaysian Islamic home financing bay' bithaman al-ajil ('BBA') compatible with Islamic law? A critical examination on the issue of 'beneficial ownership"'. Mediterranean Journal of Social Sciences, 8 (2), 27-36.

Md Dahlan, N.H., Shuib, M.S., \& Mohd Noor, F. (2017b). "Issues in bay' bithaman al-ajil Islamic home finance ('BBA') in abandoned housing projects in Malaysia: an examination of 'gharar'”. Journal of Law, Policy and Globalization, 57, 122-132.

Md Dahlan, N.H., Syed Abdul Kader, S, Z. (2011). "Shariah and legal issues in house buying in Malaysia: The legality of Bay'Bitham-Al-Ajil('BBA') with special reference to 
6-8 August 2021

Budapest, Hungary

abandoned housing projects". Pertanika Journal of Social Sciences \& Humanities, 19 (2), 349-361.

Md Dahlan, NH, \&, Md Desa, R. (2010). "Rehabilitation of abandoned housing projects: A comparative analysis on laws and practices in Peninsular Malaysia, New South Wales and Australia". US-China Law Review, 7 (8), 1-26.

Md Dahlan, NH, (2008b). "The Need to Define 'Abandoned Housing Project' in Peninsular Malaysia: An Analysis". IIUM Law Journal, 16 (1), 85-107.

Ministry of Housing and Local Government, Division of Supervision and Enforcement. (n.d). Senarai Projek Perumahan Swasta Terbengkalai Tahun 1999. Kuala Lumpur: Author, n.d.

Ministry of Housing and Local Government. (n.d). Buku Panduan Pelaksanaan Pusat Setempat Bagi Cadangan Pemajuan. Kuala Lumpur: Author.

Muhammad, S.R.S., \& Ahmad, F.S.A (2014). The behaviour of profit of Musharakah Mutanaqisah partnership homeownership by the case of abandoned housing project. AIP Conference Proceedings. 1067-1072. DOI: 10.1063/1.4887739.

Mumin, M.Y., Zainol, F.A., \& Wan Daud, WN (2017). Solving abandoned residential housing projects in Malaysia: findings from blue ocean strategy. International Journal of Business Process Integration and Management, Volume 8, Issue 4, 243-251. DOI: 10.1504/IJBPIM.2017.088798

Perbadanan Pengurusan Trellises \& Ors V. Datuk Bandar Kuala Lumpur \& Ors [2021] 2 CLJ 808 (Court of Appeal at Putrajaya).

Portal Rasmi Jabatan Perumahan Negara, Kementerian Perumahan dan Kerajaan Tempatan. (2018). Projek Perumahan Terbengkalai. Retrieved from https://ehome.kpkt.gov.my/index.php/pages/view/206

Portal Rasmi Jabatan Perumahan Negara, Kementerian Perumahan dan Kerajaan Tempatan. (2012). Projek Perumahan Terbengkalai. Retrieved June, 9, 2020 from https://ehome.kpkt.gov.my/index.php/pages/view/206

Public Authorities Protection Act 1948 (Act 198) (revised 1978).

Salam, S.A., Ariffin, NF, Nur Aseykin, R., Noram, M.I.A., \& Ramli, I. (2019). Effect of government policy towards the abandoned housing project in Malaysia. In: Proceedings of 3rd National Conference on Wind \& Earthquake Engineering and 1st International Seminar on Sustainable Construction Engineering (NCWE \& ISSCE 2019), 12-13 July 2019, Kuala Lumpur, Malaysia, 227-235.

Shahrul Annuar. S. (2019, 8 March). Roboh Highland Towers selewat-lewatnya Jun - Zuraida. BHOnline. 
Siew-Nooi, P. \& Tech-Hong, T. (2016). "Challenges of Implementing Build-Then-Sell Housing Delivery System to Address the Abandoned Housing Projects in Malaysia". Malaysian Journal of Economic Studies, 53(1), 135-151.

Silverman, D. (2000). Doing Qualitative Research, A Practical Handbook. London: SAGE Publications Ltd.

Silverman, D. (2005). Doing Qualitative Research, A Practical Handbook (2 ${ }^{\text {nd }}$ ed.). London: SAGE Publications Ltd.

Silverman, D. (2018). Doing Qualitative Research, A Practical Handbook (5 ${ }^{\text {th }}$ ed.). London: SAGE Publications Ltd.

Steven Phoa Cheng Loon \& Ors v Highland Properties Sdn Bhd \& Ors [2000] 4 MLJ 200; [2000] 3 AMR 3567 (High Court of Malaya at Kuala Lumpur).

Street, Drainage and Building Act 1974 (Act 133).

The Star. (2004). AmFinance agrees to payout | The Star. Retrieved April 16, 2021, from https://www.thestar.com.my/news/nation/2004/06/02/amfinance-agrees-to-payout

Sulaiman, Z., Ali, A.S., \& Ahmad, F. (September 2012). Abandoned Housing Project: Assessment On Resident Satisfaction Toward Building Quality. Open House International. Gateshead, Vol. 37, Iss. 3, 72-80.

Tropiland Sdn. Bhd. v. Majlis Perbandaran Seberang Perai [1996] 4 MLJ 16 (High Court of Malaya at Penang).

Uniform Building By-Laws 1984 (GN.5178/84).

Wikipedia. (2020). Highland Towers Collapse. Retrieved 12 June, 2020 from https://en.wikipedia.org/wiki/Highland_Towers_collapse

World Top 20 Projects. (2019). Global Movement - Government Transparency The Sustainable Development Goals (SDG). Retrieved from https://worldtop20.org/globalmovement?gclid=EAIaIQobChMI89LQvNHF6gIVRiUrCh0HkgCBEAAYASAAEgLZ1 _D_BwE

Yin, R. K. (2003). Case Study Research, Design and Methods (3 ${ }^{\text {rd }}$ ed.). London: SAGE Publications Ltd.

Yin, R.K. (2014). Case Study Research, Design and Methods (5 $5^{\text {th }}$ ed.). London: SAGE Publications Ltd.

Zahrah, M. (1998). Research Methods for Law Postgraduate Overseas Students. Kuala Lumpur: Stilglow Sdn Bhd. 